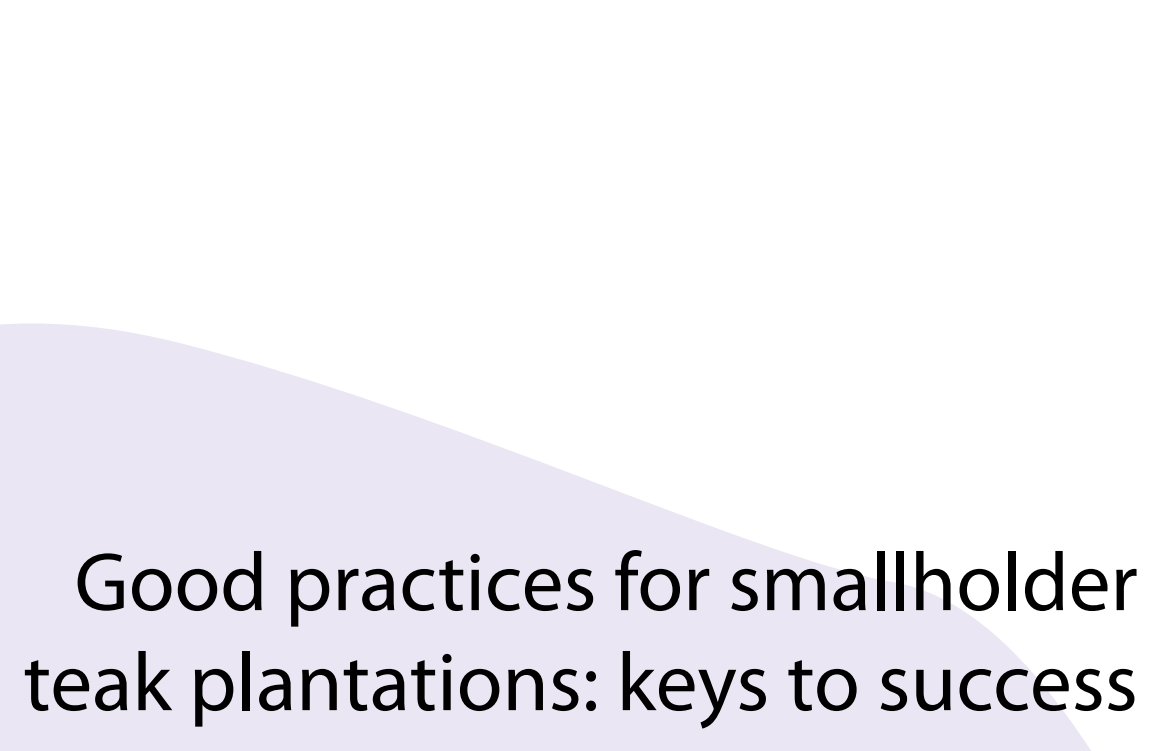

Olavi Luukkanen and Mark Appiah 



\section{Good practices for smallholder teak plantations: keys to success}

Olavi Luukkanen and Mark Appiah

Working Paper no 173 
LIMITED CIRCULATION

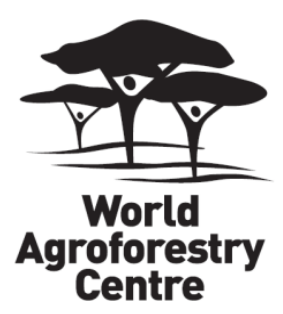

\section{Correct citation}

Luukkanen O, Appiah M. 2013. Good practices for smallholder teak plantations: keys to success. Working Paper 173. Bogor, Indonesia: World Agroforestry Centre (ICRAF) Southeast Asia Regional Program. 16p. DOI: 10.5716/WP13246.PDF

Titles in the Working Paper Series share interim results on agroforestry research and practices to stimulate feedback from the scientific community. Other publication series from the World Agroforestry Centre include agroforestry perspectives, technical manuals and occasional papers.

Published by the World Agroforestry Centre

Southeast Asia Regional Program

PO Box 161, Bogor 16001

Jawa Barat

Indonesia

Tel: +62 2518625415

Fax: +62 2518625416

Email: icraf-indonesia@cgiar.org

Website: http://worldagroforestry.org/regions/southeast_asia

(C) World Agroforestry Centre 2013

\section{Disclaimer and copyright}

The views expressed in this publication are those of the authors and not necessarily those of the World Agroforestry Centre. This publication may be quoted or reproduced without charge, provided the source is acknowledged. All images remain the sole property of their source and may not be used for any purpose without written permission of the source. 


\section{About the authors}

Olavi Luukkanen is professor emeritus in tropical silviculture and former director of the Viikki Tropical Resources Institute at the University of Helsinki, Finland. He holds MSc degrees in forestry and genetics from the University of Helsinki and in tree physiology from the University of Wisconsin, Madison, USA. He obtained a DSc (Agr.\&For.) degree from the University of Helsinki in 1978. Since 1982 he has led educational, research and development projects related to tropical forests in several countries in Asia and Africa. His international activities have covered the chairmanship of the European Tropical Forestry Network and currently include membership of the World Agroforestry Centre's board of trustees and observer membership of the Center for International Forestry Research's board of trustees. He was awarded the Neilein First Class decoration of Sudan in 2005 and an honorary doctoral degree in tropical forestry at Kasetsart University, Bangkok, in 2012. He has published about 300 scientific and other professional articles and book chapters, and supervised or cosupervised about 40 doctoral theses on tropical forests.

Mark Appiah is an adjunct professor of tropical forestry at the University of Eastern Finland in Joensuu, Finland. He began his university education in Ghana and then obtained an MSc degree in agroforestry from the Royal Veterinary and Agricultural University, Copenhagen, Denmark, and, in 2003, a DSc (Agr.\&For.) degree in tropical silviculture at the University of Helsinki, Finland. He also has a temporal position as principal research scientist in agroforestry at the Centre for Scientific and Industrial Research, Forestry Research Institute of Ghana. He also leads courses in ecosystem management and forest fire management at the Graduate School run by the University of Eastern Finland and the Centre for Scientific and Industrial Research, Forestry Research Institute of Ghana. He has managed and implemented a number of international projects in Ghana and written over 20 publications in refereed international journals and textbooks. He is also a member of various forestryrelated professional associations and a reviewer for six international journals. 


\section{Abstract}

Traditionally teak has been grown in government or enterprise-controlled large plantations, although commonly applying agroforestry practices for the benefit of local people. However, experiences from many countries show that smallholder farmers can become major suppliers of industrial teak wood while at the same time improving their livelihoods. Countries such as India or Thailand, which fall within the natural range of teak forests, tend to have more regulation and restrictions and fewer national or local incentives for promoting teak in individual or communal teak plantations than does, for instance, Ghana, where teak is grown as an exotic species. In South and Southeast Asia there are already examples of how remaining constraints to smallholder teak management can be removed, but new national and international efforts are needed to speed this development. Agroforestry offers a valuable approach for smallholder-based teak production, but this potential is still restricted by segregated perceptions on agriculture and forestry in policies, legislation and institutions.

Keywords: Community forestry, agroforestry, forest policy, India, Thailand, Ghana 


\section{Acknowledgements}

Valuable information has been received from Dr DN Tewari (India) and Dr Suree Bumibhamon (Thailand). The authors are solely responsible for opinions expressed in this paper. 



\section{Contents}

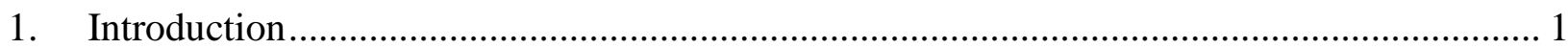

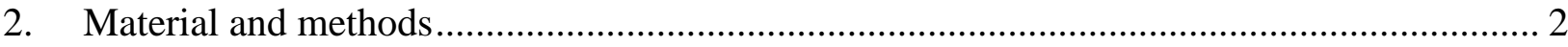

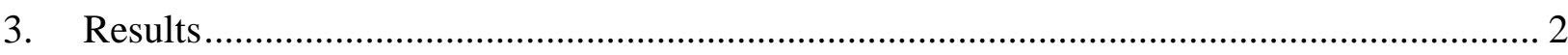

3.1 India 2

3.2 Thailand 3

3.3 West Africa: the case of Ghana $\quad 5$

3.4 Agroforestry as a management approach for teak 7

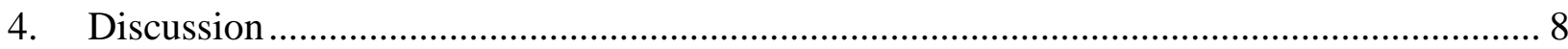

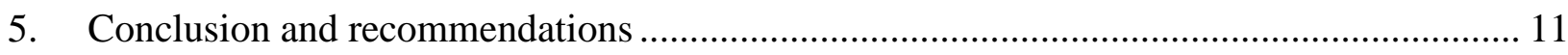

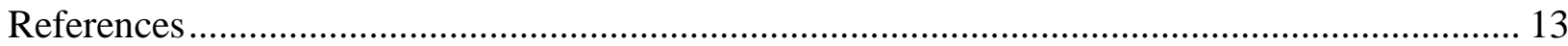

- vii - 



\section{Introduction}

Teak (Tectona grandis) has been an agroforestry tree species from the very beginning of its systematic management for contemporary industrial purposes. The long experience of combined management of teak with agricultural crops undoubtedly helps us in understanding the associated management options and in developing improved teak plantation management practices that suit the specific needs of people in the present-day world (Evans and Turnbull 2004, p. 26).

Persson (2003) has highlighted the 'paradigm changes' in global forestry, which came after industrial plantations first were promoted in tropical countries as drivers for economic and social development in the 1950s and 1960s. Limited success in this approach led to a focus on social forestry, especially from the late 1970s. Starting in the late 1980s, environmental issues became the main theme in the international forest policy debate, leading to the adoption of global conventions on climate, biodiversity and desertification after the world environmental summit in 1990 in Rio di Janeiro. Persson concludes that we have, since the mid-1990s, been under yet another forestry paradigm, which has the improvement of local livelihoods as its main aim. Roshetko et al. (2008) confirm that a paradigm shift in forestry specifically relates to giving smallholder farmers a greater role in forest management and to giving better recognition to growing trees in agroforestry systems.

The Tropical Forestry Action Plan launched by the Food and Agriculture Organization of the United Nations in 1985 (FAO 1985) was a major attempt to achieve a balance between different aspects of forestry development and between economic, environmental and social aims. National-level forestry planning was given a strong framework by the final report of the Intergovernmental Panel on Forests (IPF) published in 1997 (UN Economic and Social Council 1997).

In reference to teak, it has been repeatedly stated that existing policies and legislation are in many countries posing a serious limitation to private initiatives in teak plantation management (Enters 2000; for Thailand, cf. Mittelman 2000). This involves tenure insecurity as well as complex regulations on harvesting, timber transport, taxation and royalties. At the regional conference, facilitated by the FAO's Forestry Research Support Programme for Asia and the Pacific and TEAKNET, held in Thailand in 1999, it was suggested that new incentives be created for promoting private teak plantation management (Enters 2000).

Even coordinated attempts to change existing forestry policies may fail if there is no general national agreement on forestry issues or willingness to reach one. For instance, in Thailand an early attempt to develop a national forest programme with much focus on smallholder forest management, the Thai Forestry Sector Master Plan project, did not lead to any substantial change in policies or management practices (cf. Ministry of Agriculture and Cooperatives 1993 a,b; Hares 2008).

With this background, the present paper attempts to analyse the policy frameworks for plantation forestry and teak growing in particular. Examples were taken for comparing the situation in countries where teak is an indigenous species (India, Thailand) with those in West Africa, with Ghana as a case study. Another specific aim was to investigate how contemporary agroforestry could respond to new challenges in teak plantation management. 


\section{Material and methods}

This paper is a literature review based on available reports. Valuable information has also been obtained from key informants in different countries, as recognized in the Acknowledgements.

\section{Results}

\subsection{India}

The India State of Forest Report (Government of India 2011) gives an updated account of the forestry situation in the country. The growing stock of India's forests is estimated to be 6050 million $\mathrm{m}^{3}$. Significantly, out of this volume, 1550 million $\mathrm{m}^{3}$ or $26 \%$ is found outside the actual forest area and mainly managed by smallholder farmers. Of the total growing stock, $4.6 \%$ consists of teak, which is the most common species in forest plantations in the country. The total area of teak plantations is reported as 1.7 million ha. The official figures indicate a relatively low annual deforestation rate of about 40000 ha for the country, but some discussion on the interpretation of forest inventory figures is continuing (cf. Gilbert 2012).

Planting of teak in India faces problems because of restrictions in many states requiring permissions from the Forest Department for both felling and transporting teak timber; this has caused the annual rate of planting to decrease recently (Dr Dina Tewari, personal communication).

According to Persson (2003), the social forestry programmes supported in many Indian states by the World Bank and other donors in the 1980s are a rare example of successful donor-funded forestry projects. His conclusion is that the reason they were soon suspended was that the results and experiences were not fully analyzed.

Starting in 1990, Joint Forest Management (JFM) became the mainstream activity for supporting community-based forest management in India; its introduction has been described as the most important event in Indian forestry since independence (Kashwan 2003). JFM has achieved positive results which, however, have greatly varied among different states, depending on the efforts of state forestry administrations (Faust 1998). Kant and Cooke (1998), in their study of the initial success of JFM, also emphasized that conflict resolution is often lacking in JFM schemes and must be guaranteed for JFM to achieve its goals.

Dahal et al. (2011) stated that the Forest Rights Act of 2006 was an important landmark in India strengthening the role of local people, including those living in traditional tribal communities, but its potential as an agent for change has been diluted by weak implementation and conflicting interests between different actors in land-use.

It is clearly recognized in India that farmers and communities are in key position for fulfilling the national goal of $33 \%$ forest cover stated in the National Forest Policy. There is already a rapid rise in tree cover in agroforestry systems in India, and this gives new opportunities for growing teak by 
smallholder farmers. Under the Ministry of Environment and Forests, the National Afforestation and Eco-development Board will have the responsibility to coordinate the efforts for gaining the targeted forest cover for the whole country within the framework of the National Afforestation Programme initiated in 2002. This programme has a multi-level institutional setup consisting of 1) the State Forest Development Agency (SFDA) at the State level; 2) Forest Development Agencies at the forest division level; and 3) Joint Forest Management Committees) or their equivalents at the village level. The focus of the institutional work would be '.. towards regeneration and management of forest resources while strengthening the village-level capacity for the same' (Government of India 2009).

Observations on the implementation of the new programme in India show positive results and also indicate that teak could well re-occupy its position as the most important planted tree species in the country, this time with the support to farmers and with all the benefits this tree species can bring in terms of local livelihoods, economic development and environmental benefits. There are also attempts to link this new teak planting activity to REDD+, carbon trading and other climate-change schemes, but there are several risks, common to all community-based approaches in climate-change mitigation or adaptation, that have not yet been fully analyzed (RECOFTC 2011).

\subsection{Thailand}

Thailand has a long history of teak plantation management, starting from government efforts in Phrae province in 1906. Planting of teak was accelerated in 1945 when a national programme was launched and implemented by the Royal Forest Department (RFD). For industrial utilization of state forests, a specialized agency, the Forest Industry Organisation (FIO), was established in 1956 (Thueksathit 2009, Blaser et al. 2011).

Regarding the total area of teak plantations in Thailand, the data given by Thaiutsa in 1999 are still commonly referred to. According to this information, the area of industrial teak plantations in Thailand in 1998 was about 300000 ha, 69\% of which was owned by RFD, 27\% by FIO and $4 \%$ by the private sector. This does not include teak planted on farms (Thuaksathit 2006). For comparison, FAO (2009) reports that the total teak planting area in Thailand in 2000 (including plantations converted to other uses) was 839000 ha. For another comparison, Blaser et al. (2011) report the area of state-owned planted, semi-natural teak forests in 2010 as 251000 ha; this indicates a difficulty (common when local tree species are planted within natural forest areas) in distinguishing plantations from natural forests.

The introduction of a logging ban in natural forests in 1989 caused a significant shift in the whole forestry sector in Thailand. The mechanical forest industry was forced to rely on imported timber and then increasingly on rubberwood. As an attempt to involve the private sector in the rehabilitation of degraded forest lands, the Reforestation Act was created in 1992. It also waived royalties for wood harvesting in reforested areas and thus made it easier for individual landowners to manage small-scale plantations (Lakanavichian 2001, 2006).

In addition, since 1994, the RFD has promoted several specific plantation programmes in order to promote the establishment of commercial tree plantations by various actors ranging from industrial enterprises to smallholder farmers. Intensive development of large-scale commercial plantations was thus initiated, bringing with it new economic opportunities, but, especially on deforested state lands, also serious conflicts related to land tenure, environmental consequences and national development 
goals in general (Barney 2005). This is still a serious concern, considering that more than one million households still reside on forest land without legal provision of land-use rights (Yasmi et al. 2011).

On private agricultural land, the situation was simpler and individual landowners became increasingly interested in the establishment of tree plantations, which, however, were usually established with fastgrowing species, such as eucalypts, mainly in the northeast of the country, on land previously used for cassava cultivation. As pointed out by Barney (2005), the Reforestation Act of 1992 also had serious weaknesses that were related, for instance, to unclear land-use rights of settlers in deforested areas and to the obligations and rights of industrial plantation owners, as well as to plantation registration procedures. At the beginning, the Act also specifically focused on teak as one of the indigenous species recommended for planting, although the number of species covered by it has later increased.

The whole process of the gradual privatization of forestry still underway in Thailand is in line with what Jonathan Rigg (Rigg 2003) has described as the 'changing human landscape' of Southeast Asia. It refers to traditional agricultural production giving way for new economic activities as the rural population is increasingly attracted by industrial work in urban centres but also pushed out from rural life because of economic, social and environmental constraints in the traditional village. The potential positive role of forestry in this process, even if referred to in that analysis, has probably not been fully recognized in Thailand.

In Thailand, since the early 1990s the question of community forestry has gained importance to the extent that the whole issue became over-politicized and temporarily ended in a deadlock. The Community Forestry Act has not yet been approved and its future implementation is also opening up new questions (cf. Dahal et al. 2011). It also seems that there is suspicion both among government authorities and in civil society concerning the capacity of local communities to manage their own forests (Blaser et al. 2011); this is, however, in sharp contrast to what Hares (2008) concluded in her studies on perceptions of forests and traditional forest management by local communities in northern Thailand.

It has been concluded in several reviews (cf. Lakanavichian 2001, 2006; Blaser et al. 2011), that community and smallholder farmers involvement could become a mainstream activity in commercial tree growing in Thailand and also a principal tool for forest rehabilitation. For teak to be an attractive species in this situation, changes are needed both in management practices and, most importantly, in supporting policies and legislation. Teak agroforestry combined with rice cultivation, as already practised in Java, Indonesia, could be introduced as a new silvicultural solution. Remaining unnecessary regulations attached to teakwood harvesting and transport should be removed, and access to markets should be facilitated using suitable policy measures or partnerships with enterprises, as already done in the Southeast Asia region in such countries as Indonesia (Kallio 2012, 2013) and Laos (RECOFTC 2012).

In Thailand, teak management on agricultural land by individual farmers would probably easily expand once the remaining regulatory constraints are removed. Teak should, indeed, be compared in this respect to rubberwood or agricultural crops such as cassava. For community forestry on state forest land, when forest ecosystem restoration is the main aim, this would be more difficult to accomplish. As outlined by Lakanavichian (2006), this could, however, be achieved with two slightly different approaches, community forest management with timber production, or collaborative forest rehabilitation. 
Community forestry with timber production would incorporate lands already under community management, as well as degraded state forest lands managed jointly by the community or individually by farmers. As suggested by Lakanavichian (2006), extension services could be provided by suitable agencies, such as the RFD, and agroforestry systems would be encouraged. A wide range of species would be available for use but incentives would be given to grow indigenous trees, such as teak.

On the other hand, if the aim is large-scale forest rehabilitation, the lead could be taken by RFD, which would then enter into agreements with communities covering the responsibilities as well as the modes of benefit-sharing. The emphasis would again be on indigenous species, with teak certainly a leading one (Lakanavichian 2006). This approach resembles the old application of the taungya system in Thailand (cf. Barney 2005), which was led by the RFD and Forest Industry Organization, with the significant difference that benefits from trees would also be accrued by the community following an agreement between RFD and the local community or individual farmers.

In fact, forest management reform, which is continuing in Laos and giving both communities and individual farmers considerable rights to manage and utilize forests for commercial timber production, is advocating a similar approach, using mainly fallow lands after shifting cultivation for reforestation purposes and also providing microfinancing and a certification scheme for smallholder and community teak growers (RECOFTC 2012). In Thailand, much of the current controversy in forest conservation and management (and in the whole protracted process for a community forest act) centres on the rights of communities living inside conservation forest areas (cf. Hares 2008).

For community-based rehabilitation and management of degraded forest lands outside conservation areas, a consensus on the way forward could be more easily achieved. Community-based plantation management, with communal or individual farmer approach, would definitely increase the importance of teak in achieving economic, social and environmental benefits both locally and for the whole country (Blaser et al. 2011).

\subsection{West Africa: the case of Ghana}

In a study of Africa's vegetation changes reported by the International Union for the Conservaiton of Nature (IUCN 2006), the rate of deforestation in Ghana is about 3\% per year (Appiah et al. 2012). Ghana's strategy to address deforestation and the challenges of natural resource management is largely embodied in the National Environmental Action Plan 1990-2000, the Forest and Wildlife Policy of 1994, the Forestry Development Master Plan 1996-2000, the National Land Policy of 1999, the Science and Technology Policy 2000, and the Action Plan for Science and Technology Management (FAO 2004, FC 2006).

A Forestry Development Master Plan for 1996-2020 was launched as part of the implementation of the Forest and Wildlife Policy of 1994. The aim of the plan was to promote private plantation development, with a target of 10000 ha/year for 20 years. This led to the establishment of a Forest Plantations Development Centre at Akyawkrom near Kumasi (Insaidoo et al. 2012) and a Forest Plantations Development Fund (through the Forest Plantation Development Fund Act 2000). The initial capital was generated from the proceeds of a timber export levy under the Trees and Timber (Amendment) Act 1994 (Act 493) (FAO 2002, 2004). The Forest Plantation Development Fund Act 
2000 establishes rights of ownership over timber produced to beneficiaries of the fund. This encouraged small-scale farmers in off-reserve areas to engage in on-farm tree planting.

Two main reforestation strategies emerged: 1) government-owned industrial plantations under the Government Plantation Development Programme; and 2) the modified taungya system (MTS). In September 2001, the President of Ghana launched the National Forestry Development Programme with an ambitious annual planting target of 20000 ha. The initiation of this programme has resulted in a sharp increase in the total forest plantation estate, now estimated to be over 160000 ha (FAO 2006). This corresponds to a more than $60 \%$ increase in total plantation estates within five years.

The reforestation programme also relies on private-sector involvement, particularly through taungya agroforestry practices by local farmers on areas of degraded forest reserves.

A total of 88000 ha of degraded forest reserve land were reforested under the MTS between 2002 and 2008 (FC 2008).

The MTS is a co-management arrangement between the Forestry Commission and local communities. Under this scheme, farmers are co-owners of trees and are allowed to interplant food crops during the early years of plantation establishment. It differs from the old taungya system (suspended in 1984) in giving farmers a $40 \%$ share in the timber benefits. Under the MTS, interested farmers organize themselves in MTS groups, which collectively apply for a piece of degraded forest reserve land to establish a plantation (Agyeman et al. 2003, Appiah et al. 2012). There are two lines of implementation of the MTS: the National MTS (implemented and coordinated by the Forest Services Division) and the MTS under the Community Forest Management Project (CFMP). The difference is that under the CFMP (which ended in 2010) funds from the African Development Bank were available to pay MTS farmers for their work on peg cutting and to initiate complementary incomegenerating projects for the period between canopy closure (when planting food crops is no longer possible) and timber harvesting. The CFMP also stressed capacity building and social organization (Appiah et al. 2012, Insaidoo et al. 2012).

Plantation tree species: Tree species used for plantations are mainly exotic, including gmelina (Gmelina arborea), Eucalyptus spp, cedrela (Cedrela odorata) and teak. Teak is the most dominant forest plantation species in Ghana and adopted by most farmers as an MTS species. These species have generally had better success than indigenous species because of the absence of serious pest problems.

There is no specific policy targeting the choice of plantation tree species but the situation is changing with increasing interest in local tree species such as Ceiba pentandra, Alstonia boonei, Terminalia ivorensis, Khaya ivorensis, Terminalia superba, Triplochiton scleroxylon and Pericopsis elata to be used.

Reasons for increased interest in local species or for reduction in teak production can be listed as follows (cf. Appiah et al. 2012).

- There is the perception that teak degrades the soil.

- In most cases of teak plantation establishment, teak has had limited conservation benefits because it is often designed to support the timber industry or create jobs. 
- Teak is unable to provide most of the non-timber forest products normally obtained from local species.

- Some planted food crops were not compatible with teak, leading to reduced tree or crop growth.

- Teak as other plantation tree species competes for farmland, consequently, farmers might deliberately kill planted seedlings to extend their tenure over portions of land, since a successful plantation meant discontinuation of cultivation on allocated plots.

- Inadequate financing mechanisms.

- Existing policy incentives for the private sector are mainly in the form of tax benefits on imports of machinery that favour mainly the large-scale investors.

As of 2010, plantation development policy emphasized institutional partnerships between the Forestry Commission and the district assemblies and traditional authorities, particularly the holders of 'stool land', that is, land held under customary tenure. Landowners make land available for reforestation in return for a share in the benefits. District assemblies also employ youth for reforestation activities.

Market prospects for teak in Ghana. Despite the interest in planting local species, teak plantations are still dominant among small-scale farmers owing to their easy cultivation, fast growth, resistance to fire, tolerance to a wide range of soils and rainfall, and superior wood and woodworking qualities.

Teak wood is extensively used in Ghana for diverse purposes, including furniture, roofing, crafts and poles. Among teak users are, for instance, the over 41000 small-scale registered carpenters and furniture workers. The small-scale carpenters represent the largest group of teak users. They require $219000 \mathrm{~m}^{3}$ of sawn timber annually. This represents about $72 \%$ of the total domestic timber requirement for the entire country. There are about 130 wood-processing units and 200 other enterprises focusing on furniture production (Agyarko 2000) that also utilize teak.

There is an increasing international market for teak from Ghana. Currently, Ghana exports teak to South Africa and India. Teak is now a major component of the forest economy of Ghana.

With depleting local species and slow growth following establishment, fast-growing trees such as teak will continue to dominate the plantation wood market in Ghana for years to come.

Form Ghana Ltd. is a forest plantation management company based in Central Ghana (Kumasi). It started substantial investment in 2007 in high-quality teak plantations and a commercial-scale nursery located in Akumadan, Ashanti region. Form Ghana is one of the very few large-scale teak producers in Ghana, with more than 600 ha of teak plantations and a production capacity for planting 700000 seedlings of teak per year (Form Ghana 2013).

\subsection{Agroforestry as a management approach for teak}

The systematic management of teak forests started in colonial British India and has continued to the present day all over the tropical world by commonly applying agroforestry practices in plantation establishment (the taungya system and similar approaches elsewhere). However, a distinct disadvantage in this system was the exclusion of farmers from the benefits brought about by trees (Evans and Turbull 2004, p. 320-322). 
Van Noordwijk et al. (2008) concluded that a divide between agricultural and forestry policies has been recognized as a barrier for developing agroforestry practices that have smallholder farmers as the main beneficiaries of plantation agroforestry. These authors point out the exclusion of agroforestry systems from common definitions of 'forest' as a problematic issue. Consequently, they recommend more attention be paid to developing both national and international policy initiatives to achieve a 'level ground' for plantation forestry and agroforestry management and seeing them as strongly synergetic management options. In their opinion, this would mean a shift from primarily supporting large-scale plantation operations to also giving support, in every possible form but not creating specific privileges, to smallholder farmers who grow trees in their own agroforestry systems.

According to the same authors, basing plantation management on an agroforestry approach from the very beginning can eliminate such challenges to plantation forestry as conflicts over land-use rights between local communities and the government or industrial companies. They also emphasize that for more than a century, foresters have been involved in various attempts to involve local communities in forest management but only in recent times has there been a real opportunity to remove existing bottlenecks (including deficient quality assurance and market access, poor rewards for environmental services and, most importantly, weak institutional and legal frameworks). We should now make full use of the concept of integrated, multifunctional landscapes, in contrast to the past practice of segregated functions for agriculture and forestry (van Noordwijk et al. 2008).

Wood provided by smallholder farmers already forms a substantial part of all commercial wood available. This highlights the need to fully recognize 'trees outside forests' as a main factor in national, local and household economies and to expand the scope of forestry beyond its conventional domain (Roshetko et al. 2008).

Very recent initiatives (cf. FAO 2013) have indicated that new global understanding is developing for agroforestry as a feasible approach for 'regreening' activities that create benefits locally as well as for nations as a whole.

In reference to teak in Indonesia, Kallio and her co-workers (Kallio et al. 2011, 2013) were able to analyse the primary reasons for planting teak, which were using trees a 'savings' account for predicted or unexpected household expenditures, and planting teak on land that could not be used for continuous farming because of low soil fertility. Needs for construction timber in the household were also mentioned. The relatively long rotation in Indonesian teak plantations (20 years upwards for first harvesting) did not seem to be a constraint.

\section{Discussion}

India and Thailand, which both have teak resources in natural forests as well as in plantations, are characterized by a long history of management and utilization of this species and by significant achievements in related research. In both countries, policies and legislations have recognized a special role of teak in economic development and the cultural and environmental heritage. 
This recognition has led to successful activities in teak plantation management in both countries. It has contributed, through policies, legislation and regulations, initially to a plantation ownership model where the government and industrial enterprises are heavily involved as owners or managers. A similar situation existed for a long time in Indonesia, where teak is not indigenous but has nevertheless been grown in plantations for centuries (Pandey and Brown 2000).

There are important developments both in India and in Thailand that support an increased use of teak as plantation species. Community forestry and farm forestry are becoming central approaches for plantation management. In India, the central driver for change is the National Afforestation Programme, initiated in 2002, which explicitly aims at strengthening village-level action in forest management (Government of India 2009).

In Thailand, only recently has a forest policy been outlined that would not only recognize the urgent need for forest rehabilitation using indigenous species, such as teak, but which would also give local communities and individual farmers a new central role in it.

The Thailand Forestry Outlook Study (FAO 2009) has presented precise new models for growing of teak and other plantation species for commercial purposes in the country, including a proposal for new organisations for both wood producers and wood users. Lakanavichian $(2001,2006)$ had earlier concluded that there is enough information for simultaneously tackling the need for forest rehabilitation, income generation for the rural population, and provision of raw material for wood industries. A finalised legal framework and exact forms of implementation of new policies are unfortunately still lacking (Dahal et. al. 2011).

Long rotations are commonly seen as a problem in growing teak, especially in farm forestry. In a study comparing the profitability of fast-growing plantation species with that of teak in Thailand, Niskanen et al. (1993) suggested several ways to overcome this constraint. The most efficient way would be to use a short rotation for teak (e.g. 25 years). Coppicing as a regeneration method in this species could also be more widely used. Special attention should be paid to the use of proper silvicultural methods, so as to improve the wood quality, which also would be positively affected by using agroforestry practices in on-farm teak growing. Using financial, economic or environmentaleconomic profitability as criteria, these authors concluded that teak plantations, even with a short rotation, could not compete with rubber plantation management in profitability but they performed relatively well in comparison to fast-growing forest plantations.

Compared to India or Thailand, West Africa (with Ghana as an example, above) presents a very different case in teak plantation management. The significant role of teak for national economic wellbeing, as well as for local livelihoods, has been explicitly stated in policy and legislation. The Government of Ghana has actively contributed to the development of a teak-based forest sector, even to such an extent that a new trend is now also to pay more attention to indigenous timber species in new plantations. This is unlikely to decrease the popularity of teak, however.

Recently (cf. Kalame et al. 2011), attention has also been paid to the fact that a 'win-win' practice for forestry and climate-change adaptation has already been created in Ghana by promoting the MTS for teak and for local timber species. The supporting policy instruments already in place also provide a good basis for climate-change adaptation. These researchers used the Adaptation Policy Framework, 
already recommended by international agencies, such as the United Nations Development Programme and the Intergovernmental Panel on Climate Change, as a useful tool for country-level frameworks.

Looking at other countries, community involvement in teak plantation management is increasing in Indonesia. This includes changing the management model for plantations previously owned by state companies. As shown by Nawir et al. (2007) for locations in West Nusa Tenggara province, financial viability can be good and result in substantial revenue for the community. However, the authors of this report mention as potential constraints unclear land-use rights in former state plantations and the limited capacity of government to coordinate activities.

The integration of community-based or individual teak management with wood processing and marketing is also a distinct feature in Indonesia. In Indonesia there is, however, an obvious need to develop new silvicultural guidelines and offer technical assistance for teak cultivation, which would then guarantee a better quality of teak products (Roshetko et al. 2012). In Indonesia, smallholdermanaged plantations have the potential to create sustainable economic, environmental and social benefits for their growers if trees are integrated in the production system following well-established local practices. Benefits seem to be accrued especially if the costs of tree planting and management can be reduced; farmers also have the ability to quickly adapt to new marketing opportunities (Pokorny et al. 2010). These investigators found, however, several potential risks in farmer-led schemes, including poor application of available silvicultural management techniques. In addition, proposed schemes for verifying the origin of wood for the small-scale industry, such as the Timber Legality Verification System (Sistem Verifikasi Legalitas Kayu or SVLK) in Indonesia, seem to pose problems with excessively high transaction costs (Kaye 2013).

Looking at new centres for teak plantation management in Africa, South Sudan has a considerable area of teak plantations, which clearly makes this resource an important asset for post-civil war reconstruction and national development. The country also has a new forest policy that encourages tree planting by individual farmers (Husgafvel 2010). The southernmost part of the country is also ideal for integrating food production and teak growing, as already indicated by field trials.

Unfortunately, some of the already existing teak plantations (near Yei at the Ugandan border) are now giving way to intensive maize and sorghum farming, which is not based on agroforestry but monocropping (O. Luukkanen, personal observation, 2012). This situation is similar to what Holding Anyonge and Roshetko (2003) have earlier reported, with specific reference to Kenya, on conflicting extension messages from the agriculture and forestry sectors.

It is to be hoped that a balance can be found between agricultural land use and teak plantation development in South Sudan by learning from the wide experience of the World Agroforestry Centre in promoting 'evergreen agriculture', that is, continuous management of trees and food crops together (Nair and Garrity 2012). As a whole, the full range of benefits from teak agroforestry, in contrast to pure teak plantations, should be utilized in all countries.

Overall, the concept of landscape restoration offers a useful framework for developing different, complementary activities in plantation management for different actors. Within this concept, agriculture and agroforestry management together can be made a crucial part of the solution and contribute to increased yields and better adaptation to environmental change, but the task is immense, considering that there is a total of 400 million ha of tropical lands with potential for landscape restoration (Dewees et al. 2011). 
Kanowski (2010), while also referring to the usefulness of the forest landscape restoration framework, has outlined a step-by-step approach to implement new governance regimes for provision of ecosystem goods and services for plantation forests, consisting of: 1) strengthening the knowledge base; 2) agreeing on the contributions plantation forests can have for society, specifically for different types of landscapes and societal contexts; 3) designing the appropriate governance regime; and, 4) finally, establishing the appropriate forest management practices and their monitoring systems.

\section{Conclusion and recommendations}

In tropical countries, deforestation and forest degradation still continue, while the tree cover on farmland is increasing. This is one trend that has led to a less-sharp distinction between forest and agricultural lands and which at the same time has highlighted the role of agroforestry as a management concept. Concerted efforts are needed to remove the existing distinct barriers that tend to prevent recognition of the value of tree planting in farming systems, which conventionally are not recognized as forests. A recent guide for policy-makers (FAO 2013) takes this into consideration and provides an outline of how policy can support agroforestry and how new models for teak growing could also be achieved. A feasible approach would be to highlight planted trees as components of sustainable food production systems and providers of economic, environmental and social benefits and services, primarily to the rural population but also for countries as a whole. Such an approach could be the ultimate success story for teak plantations. 



\section{References}

Agyarko T. 2000. Country forestry outlook paper: Ghana. Forestry Outlook Study for Africa Working Paper. Rome: Food and Agriculture Organization of the United Nations. Online ftp://ftp.fao.org/docrep/fao/003/ab567e/AB567E00.pdf (Accessed 11 March 2013).

Agyeman VA, Marfo KA, Kasanga KR, Danso E, Asare AB, Yeboah OM, Agyeman F. 2003. Revising the taungya plantation system: new revenue-sharing proposals from Ghana. Unasylva 212:40-47.

Appiah M. 2011. Changes in species composition in a deciduous agroecosystem in Ghana following plantation establishment. Agroforestry Systems 82:57-74.

Appiah M, Blay D, Damnyag L, Dwomoh FK, Pappinen A, Luukkanen O. 2012. Dependence on forest resources and tropical deforestation in Ghana. Environment Development and Sustainability 11(3):471-487.

Barney K. 2005. At the supply edge: Thailand's forest policies, plantation sector and commodity export links with China. Washington, DC: Forest Trends. http://www.foresttrends.org/documents/files/doc_141.pdf (Accessed 12 Feb. 2013.)

Blaser J, Sarre A, Poore D, Johnson S. 2011. Status of tropical forest management 2011. Technical Series 38. Yokohama, Japan: International Tropical Timber Organization.

Buttoud G, Ajayi O, Detlefsen G, Place F, Torquebiau E. 2013. Advancing agroforestry on the policy agenda: a guide for decision-makers. Agroforestry Working Paper 1. Rome: Food and Agriculture Organization of the United Nations.

Dahal GR, Atkinson J, Bampton J. 2011. Forest tenure in Asia: status and trends. Kuala Lumpur: European Union Forest Law Enforcement, Governance and Trade Facility.

Dewees P, Place F, Scherr SJ, Buss C. 2011. Investing in trees and landscape restoration in Africa: what, where, and how. Washington, DC: Program on Forests, World Bank.

Enters T. 2000. Site, technology and productivity of teak plantations in Southeast Asia. Conclusions and recommendations of a regional seminar organized by TEAKNET and FAO's Forestry Research Support Programme for Asia and Pacific (FORSPA) in Thailand in early 1999. Unasylva 201:55-61.

Evans J, Turnbull J. 2004. Plantation forestry in the tropics. 3rd ed. Oxford, UK: Oxford University Press.

[FAO] Food and Agriculture Organization of the United Nations. 2009. Thailand forestry outlook study. Asia-Pacific Forestry Outlook Study II. Working Paper Series APFSOS II/WP/2009/22. Bangkok: Food and Agriculture Organization of the United Nations Regional Office. http://www.fao.org/docrep/014/am617e/am617e00.pdf (Accessed 11 March 2013).

[FAO] Food and Agriculture Organization of the United Nations. 2006. Global forest resources assessment 2005: progress towards sustainable forest management. Forestry Paper 147. Rome: Food and Agriculture Organization of the United Nations.

[FAO] Food and Agriculture Organization of the United Nations. 2004. National Forest Programme Update: Ghana. Rome: Food and Agriculture Organization of the United Nations. http://www.fao.org/forestry/14844-05b211838ae49e2aea16516db606e39ab.pdf (Accessed 11 March 2013).

[FAO] Food and Agriculture Organization of the United Nations. 2002. Hardwood plantations in Ghana (Based on the work in 1998 of F. Odoom). Forest Plantations Working Papers 24. Rome: Food and Agriculture Organization of the United Nations.

[FAO] Food and Agriculture Organization of the United Nations. 1985. Tropical forestry action plan. Rome: Food and Agriculture Organization of the United Nations. 
Faust D. 1998. Conflict and cooperation in co-managed regimes: the state, local communities and shared resources in India. Working paper presented at the Sixth International Association for the Study of Common Property Conference, 10-14 June 1998, Vancouver, British Columbia. http://dlc.dlib.indiana.edu/dlc/bitstream/handle/10535/1136/ (Accessed 14 February 2013).

[FC] Forestry Commission of Ghana. 2008. National forest plantation development programme (NFPDP): Annual Report 2008. Accra: Forestry Commission of Ghana. http://76.12.220.51/assets/file/Publications/Forestry_Issues/National\%20Forest\%20Plantation\%20 Development\%20Programme/Annual\%20Reports/nfpdp_annual\%20report_2008(1).pdf (Accessed 21 February 2013).

[FC] Forestry Commission of Ghana. 2006. The 1994 forest and wildlife policy. Accra: Forestry Commission of Ghana. http://benjigyampoh.blogspot.com/2011/06/1994-forest-and-wildlifepolicy-of.html (Accessed 21 February 2013).

Form Ghana. 2013. http://www.formghana.com (Accessed 11 March 2013).

Gilbert N. 2012. India's forest area in doubt. Nature 489:14-15.

Government of India. 2011. The India state of forest report. http://www.fsi.org.in/sfr_2011. htm (Accessed 6 March 2013). New Delhi, Ministry of Environment and Forests, Government of India.

Government of India. 2009. National afforestation programme. Revised operational guidelines. New Delhi, Ministry of Environment and Forests, Government of India. http://www.iifm.ac.in/rcnaeb/naeb\%20guideline.pdf (Accessed 11 March 2013).

Hares M. 2008. Perceptions of ethnic minorities on tree growing for environmental services in Thailand. In: Snelder DJ, Lasco RD, eds. Smallholder tree growing for rural development and environmental services. Berlin: Springer Science and Business Media. p. 411-425.

Holding Anyonge C, Roshetko JM. 2003. Farm-level timber production: orienting farmers towards the market. Unasylva 212:48-56.

Husgafvel R. 2010. Global and EU governance for sustainable forest management with special reference to capacity building in Ethiopia and Southern Sudan. University of Helsinki Tropical Forestry Report 37. Viikki Tropical Resources Institute, University of Helsinki. https://helda.helsinki.fi/bitstream/handle/10138/24378/globalan.pdf?sequence=3 .

Insaidoo T, Ros-Tonen MAF, Hoogenbosch L, Acheampong E. 2012. Addressing forest degradation and timber deficits in Ghana. ETFRN News 53. Special Issue. p. 230-239.

[IUCN] International Union for the Conservation of Nature. 2006. Forest landscape restoration to meet Ghana's deforestation challenges. Gland, Switzerland: International Union for the Conservation of Nature. http://www.IUCN.org/en/news/archive/2006/newfebruary06.htm (Accessed 21 February 2013).

Kalame FB, Aidoo R, Nkem J, Oluyede C, Ajayie OC, Kanninen M, Luukkanen O, Idinobae M. 2011. Modified taungya system in Ghana: a win-win practice for forestry and adaptation to climate change? Environmental Science \& Policy 14(5):519-530.

Kallio M, Kanninen M, Krisnawati H. 2013. Smallholder teak plantations in two villages in Central Java: silvicultural activity and stand performance. Forest, Trees and Livelihoods 21(3):158-175.

Kallio MH, Kanninen M, Rohadi D. 2011. Farmers' tree planting activity in Indonesia: case studies in the provinces of Central Java, Riau, and South Kalimantan. Forests, Trees and Livelihoods 20(23):191-210.

Kanowski P. 2010. Policies to enhance the provision of ecosystem goods and services from plantation forests. In: Bauhaus J, van der Meer P, Kanninen M, eds. Ecosystem goods and services from plantation forests. Oxford, UK: Earthscan. p. 171-204.

Kant S, Cooke R. 1998. Conflict resolution: a critical factor in the success of joint forest management in India. Working paper. http://dlc.dlib.indiana.edu/dlc/bitstream/handle/10535/4405/ (Accessed 14 February 2013). 
Kashwan P. 2003. Conflicts in joint forest management. Cases from South Rajasthan. Community Forestry 4(2):12-17.

Kaye M. 2013. Small businesses band together to meet high cost of Indonesia's timber certification scheme. Forest News 6 February 2013. http://blog.cifor.org/13763/small-businesses-bandtogether-to-meet-high-cost-of-indonesias-timber-certification-scheme/\#.USL9-qVBO8A (Accessed 28 February 2013).

Lakanavichian, S. 2006. Trends in forest ownership, forest resource tenure and institutional arrangements: are they contributing to better forest management and poverty reduction? A case study from Thailand. In: Food and Agriculture Organization of the United Nations. Understanding forest tenure in Southeast Asia. Forest Policy and Institutions Working Paper 14. Rome: Food and Agriculture Organization of the United Nations. p. 325-354. ftp://ftp.fao.org/docrep/fao/009/j8167e/j8167e01.pdf (Accessed 21 February 2013).

Lakanavichian S. 2001. Impacts and effectiveness of logging bans in natural forests: Thailand. In: Durst P, Waggener TR, Enters T, Cheng TL, eds. Forests out of bounds: impacts and effectiveness of logging bans in natural forests in Asia-Pacific. Bangkok: Office for Asia and the Pacific, Food and Agriculture Organization of the United Nations. http://www.fao.org/docrep/003/X6967E/x6967e09.htm (Accessed 11 February 2013).

Mittelman A. 2000. Teak planting by smallholders in Nakhon Sawan, Thailand. Unasylva 201:62-65.

Nair R, Garrity D, eds. 2012. Agroforestry: the future of global land use. Berlin: Springer.

Nawir AA, Hakim MR, Julmansyah, Ahyar HMA, Trison S. 2007. Feasibility of community-based forestry management in partnership with a forestry district agency (case studies: Sumbawa and Bima, West Nusa Tenggara). In: Djoeroemana S, Myers B, Russell-Smith J, Blyth M, Salean IET, eds. Integrated rural development in East Nusa Tenggara, Indonesia. ACIAR Proceedings 126. Canberra: Australian Centre for International Agricultural Research. p. 150-161.

Niskanen A, Luukkanen O, Saastamoinen O, Bhumibhamon S. 1993. Evaluation of the profitability of fast-growing trees-Eucaluptus camaldulensis, Acacia mangium and Melia azedarach - as plantation tree crops in Thailand. Acta Forestalia Fennica 241.

Pandey D, Brown C. 2000. Teak: a global overview. Unasylva 201:3-13. Rome: Food and Agriculture Organization of the United Nations.

Persson R. 2003. Assistance to forestry: experiences and potential for improvement. Bogor, Indonesia: Center for International Forestry Research.

Pokorny B, Hoch L, Maturana J. 2010. Smallholder plantations in the tropics: local people between outgrower schemes and reforestation programmes. In: Bauhaus J, van der Meer P, Kanninen M, eds. Ecosystem goods and services from plantation forests. Oxford, UK: Earthscan. p. 140-170.

[RECOFTC] RECOFTC: The Center for People and Forests. 2011. REDD+, governance and community forestry: highlights from the Forest Governance Learning Group Asia Experts Meeting. Bangkok: RECOFTC: The Center for People and Forests.

[RECOFTC] RECOFTC: The Center for People and Forests. 2012. Exploring microfinance options through teak: Bokeo Province, Lao PDR. ForInfo Newsletter 2.

http://www.recoftc.org/site/uploads/wysiwyg/ForInfo\%20Newsletter\%20No\%202_4-12-12.pdf (Accessed 11 March 2013).

Rigg J. 2003. Southeast Asia: the human landscape of modernization and development. 2nd ed. Oxford, UK: Routledge.

Roshetko JM, Snelder DJ, Lasco RD, van Noordwijk M. 2008. Future challenge: a paradigm shift in the forestry sector. In: Snelder DJ, Lasco RD, eds. Smallholder tree growing for rural development and environmental services. Berlin: Springer Science and Business Media. p. 453-487.

Roshetko JM, Rohadi D, Perdana A, Sabastian G, Nuryartono N, Pramono AA, Widyani N, Manalu P, Fauzi MA, Sumardamto P, Kusumowardhani N. 2013. Teak agroforestry systems for livelihood enhancement, industrial timber production, and environmental rehabilitation. Forests, Trees, and Livelihoods 22(4) http://www.tandfonline.com/doi/full/10.1080/14728028.2013.855150. 
Ministry of Agriculture and Cooperatives. 1993a. Thai forestry sector master plan. Executive summary and proposed forestry sector policy. Bangkok: Ministry of Agriculture and Cooperatives, Government of Thailand.

Ministry of Agriculture and Cooperatives. 1993b. Thai forestry sector master plan. Sub-sectoral plan for people and forestry. Vol. 5. Bangkok: Ministry of Agriculture and Cooperatives, Government of Thailand.

Thueksathit S. 2009. Variation in growth and development of teak growing outside the natural ranges in Thailand. PhD thesis. Bangkok: Faculty of Forestry, Kasetsart University.

UN Economic and Social Council. 1997. Report of the Ad Hoc Intergovernmental Panel on Forests on its fourth session. Commission on Sustainable Development fifth session, 7-25 April 1997. New York: United Nations Economic and Social Council.

Van Noordwijk M, Roshetko JM, Murniati, Angeles MD, Suyanto, Fay C, Tomich TP. 2008. Farmer tree planting barriers to sustainable forest management. In: Snelder DJ, Lasco RD, eds. Smallholder tree growing for rural development and environmental services. Berlin: Springer Science and Business Media. p. 429-451.

Yasmi Y, Broadhead J, Enters T, Genge C. 2010. Forestry policies, legislation and institutions in Asia and the Pacific: trends and emerging needs for 2020. RAP Publication 2010/10. Bangkok: Regional Office for Asia and the Pacific, Food and Agriculture Organization of the United Nations. 


\section{WORKING PAPERS IN THIS SERIES}

\section{5}

1. Agroforestry in the drylands of eastern Africa: a call to action

2. Biodiversity conservation through agroforestry: managing tree species diversity within a network of community-based, nongovernmental, governmental and research organizations in western Kenya.

3. Invasion of prosopis juliflora and local livelihoods: Case study from the Lake Baringo area of Kenya

4. Leadership for change in farmers organizations: Training report: Ridar Hotel, Kampala, 29th March to 2nd April 2005.

5. Domestication des espèces agroforestières au Sahel : situation actuelle et perspectives

6. Relevé des données de biodiversité ligneuse: Manuel du projet biodiversité des parcs agroforestiers au Sahel

7. Improved land management in the Lake Victoria Basin: TransVic Project's draft report.

8. Livelihood capital, strategies and outcomes in the Taita hills of Kenya

9. Les espèces ligneuses et leurs usages: Les préférences des paysans dans le Cercle de Ségou, au Mali

10. La biodiversité des espèces ligneuses: Diversité arborée et unités de gestion du terroir dans le Cercle de Ségou, au Mali

11. Bird diversity and land use on the slopes of Mt. Kilimanjaro and the adjacent plains, Tanzania

12. Water, women and local social organization in the Western Kenya Highlands

13. Highlights of ongoing research of the World Agroforestry Centre in Indonesia

14. Prospects of adoption of tree-based systems in a rural landscape and its likely impacts on carbon stocks and farmers' welfare: The FALLOW Model Application in Muara Sungkai, Lampung, Sumatra, in a 'Clean Development Mechanism' context

15. Equipping integrated natural resource managers for healthy Agroforestry landscapes.

17. Agro-biodiversity and CGIAR tree and forest science: approaches and examples from Sumatra.

18. Improving land management in eastern and southern Africa: A review of policies.

19. Farm and household economic study of Kecamatan Nanggung, Kabupaten Bogor, Indonesia: A socio-economic base line study of Agroforestry innovations and livelihood enhancement.

20. Lessons from eastern Africa's unsustainable charcoal business.

21. Evolution of RELMA's approaches to land management: Lessons from two decades of research and development in eastern and southern Africa

22. Participatory watershed management: Lessons from RELMA's work with farmers in eastern Africa.

23. Strengthening farmers' organizations: The experience of RELMA and ULAMP.

24. Promoting rainwater harvesting in eastern and southern Africa.

25. The role of livestock in integrated land management.

26. Status of carbon sequestration projects in Africa: Potential benefits and challenges to scaling up.

27. Social and Environmental Trade-Offs in Tree Species Selection: A Methodology for Identifying Niche Incompatibilities in Agroforestry [Appears as AHI Working Paper no. 9]

28. Managing tradeoffs in agroforestry: From conflict to collaboration in natural resource management. [Appears as AHI Working Paper no. 10] 
29. Essai d'analyse de la prise en compte des systemes agroforestiers pa les legislations forestieres au Sahel: Cas du Burkina Faso, du Mali, du Niger et du Senegal.

30. Etat de la recherche agroforestière au Rwanda etude bibliographique, période 1987-2003

2007

31. Science and technological innovations for improving soil fertility and management in Africa: A report for NEPAD's Science and Technology Forum.

32. Compensation and rewards for environmental services.

33. Latin American regional workshop report compensation.

34. Asia regional workshop on compensation ecosystem services.

35. Report of African regional workshop on compensation ecosystem services.

36. Exploring the inter-linkages among and between compensation and rewards for ecosystem services CRES and human well-being

37. Criteria and indicators for environmental service compensation and reward mechanisms: realistic, voluntary, conditional and pro-poor

38. The conditions for effective mechanisms of compensation and rewards for environmental services.

39. Organization and governance for fostering Pro-Poor Compensation for Environmental Services.

40. How important are different types of compensation and reward mechanisms shaping poverty and ecosystem services across Africa, Asia \& Latin America over the Next two decades?

41. Risk mitigation in contract farming: The case of poultry, cotton, woodfuel and cereals in East Africa.

42. The RELMA savings and credit experiences: Sowing the seed of sustainability

43. Yatich J., Policy and institutional context for NRM in Kenya: Challenges and opportunities for Landcare.

44. Nina-Nina Adoung Nasional di So! Field test of rapid land tenure assessment (RATA) in the Batang Toru Watershed, North Sumatera.

45. Is Hutan Tanaman Rakyat a new paradigm in community based tree planting in Indonesia?

46. Socio-Economic aspects of brackish water aquaculture (Tambak) production in Nanggroe Aceh Darrusalam.

47. Farmer livelihoods in the humid forest and moist savannah zones of Cameroon.

48. Domestication, genre et vulnérabilité : Participation des femmes, des Jeunes et des catégories les plus pauvres à la domestication des arbres agroforestiers au Cameroun.

49. Land tenure and management in the districts around Mt Elgon: An assessment presented to the Mt Elgon ecosystem conservation programme.

50. The production and marketing of leaf meal from fodder shrubs in Tanga, Tanzania: A pro-poor enterprise for improving livestock productivity.

51. Buyers Perspective on Environmental Services (ES) and Commoditization as an approach to liberate ES markets in the Philippines.

52. Towards Towards community-driven conservation in southwest China: Reconciling state and local perceptions.

53. Biofuels in China: An Analysis of the Opportunities and Challenges of Jatropha curcas in Southwest China.

54. Jatropha curcas biodiesel production in Kenya: Economics and potential value chain development for smallholder farmers

55. Livelihoods and Forest Resources in Aceh and Nias for a Sustainable Forest Resource Management and Economic Progress 
56. Agroforestry on the interface of Orangutan Conservation and Sustainable Livelihoods in Batang Toru, North Sumatra.

57. Assessing Hydrological Situation of Kapuas Hulu Basin, Kapuas Hulu Regency, West Kalimantan.

58. Assessing the Hydrological Situation of Talau Watershed, Belu Regency, East Nusa Tenggara.

59. Kajian Kondisi Hidrologis DAS Talau, Kabupaten Belu, Nusa Tenggara Timur.

60. Kajian Kondisi Hidrologis DAS Kapuas Hulu, Kabupaten Kapuas Hulu, Kalimantan Barat.

61. Lessons learned from community capacity building activities to support agroforest as sustainable economic alternatives in Batang Toru orang utan habitat conservation program (Martini, Endri et al.)

62. Mainstreaming Climate Change in the Philippines.

63. A Conjoint Analysis of Farmer Preferences for Community Forestry Contracts in the Sumber Jaya Watershed, Indonesia.

64. The highlands: a shared water tower in a changing climate and changing Asia

65. Eco-Certification: Can It Deliver Conservation and Development in the Tropics.

66. Designing ecological and biodiversity sampling strategies. Towards mainstreaming climate change in grassland management.

67. Towards mainstreaming climate change in grassland management policies and practices on the Tibetan Plateau

68. An Assessment of the Potential for Carbon Finance in Rangelands

69 ECA Trade-offs Among Ecosystem Services in the Lake Victoria Basin.

69. The last remnants of mega biodiversity in West Java and Banten: an in-depth exploration of RaTA (Rapid Land Tenure Assessment) in Mount Halimun-Salak National Park Indonesia

70. Le business plan d'une petite entreprise rurale de production et de commercialisation des plants des arbres locaux. Cas de quatre pépinières rurales au Cameroun.

71. Les unités de transformation des produits forestiers non ligneux alimentaires au Cameroun. Diagnostic technique et stratégie de développement Honoré Tabuna et Ingratia Kayitavu.

72. Les exportateurs camerounais de safou (Dacryodes edulis) sur le marché sous régional et international. Profil, fonctionnement et stratégies de développement.

73. Impact of the Southeast Asian Network for Agroforestry Education (SEANAFE) on agroforestry education capacity.

74. Setting landscape conservation targets and promoting them through compatible land use in the Philippines.

75. Review of methods for researching multistrata systems.

76. Study on economical viability of Jatropha curcas L. plantations in Northern Tanzania assessing farmers' prospects via cost-benefit analysis

77. Cooperation in Agroforestry between Ministry of Forestry of Indonesia and International Center for Research in Agroforestry

78. "China's bioenergy future. an analysis through the Lens if Yunnan Province

79. Land tenure and agricultural productivity in Africa: A comparative analysis of the economics literature and recent policy strategies and reforms

80. Boundary organizations, objects and agents: linking knowledge with action in agroforestry watersheds

81. Reducing emissions from deforestation and forest degradation (REDD) in Indonesia: options and challenges for fair and efficient payment distribution mechanisms

82. Mainstreaming climate change into agricultural education: challenges and perspectives 
83. Challenging conventional mindsets and disconnects in conservation: the emerging role of ecoagriculture in Kenya's landscape mosaics

84. Lesson learned RATA garut dan bengkunat: suatu upaya membedah kebijakan pelepasan kawasan hutan dan redistribusi tanah bekas kawasan hutan

85. The emergence of forest land redistribution in Indonesia

86. Commercial opportunities for fruit in Malawi

87. Status of fruit production processing and marketing in Malawi

88. Fraud in tree science

89. Trees on farm: analysis of global extent and geographical patterns of agroforestry

90. The springs of Nyando: water, social organization and livelihoods in Western Kenya

91. Building capacity toward region-wide curriculum and teaching materials development in agroforestry education in Southeast Asia

92. Overview of biomass energy technology in rural Yunnan (Chinese - English abstract)

93. A pro-growth pathway for reducing net GHG emissions in China

94. Analysis of local livelihoods from past to present in the central Kalimantan Ex-Mega Rice Project area

95. Constraints and options to enhancing production of high quality feeds in dairy production in Kenya, Uganda and Rwanda

\section{0}

96. Agroforestry education in the Philippines: status report from the Southeast Asian Network for Agroforestry Education (SEANAFE)

97. Economic viability of Jatropha curcas L. plantations in Northern Tanzania- assessing farmers' prospects via cost-benefit analysis.

98. Hot spot of emission and confusion: land tenure insecurity, contested policies and competing claims in the central Kalimantan Ex-Mega Rice Project area

99. Agroforestry competences and human resources needs in the Philippines

100. CES/COS/CIS paradigms for compensation and rewards to enhance environmental Services

101. Case study approach to region-wide curriculum and teaching materials development in agroforestry education in Southeast Asia

102. Stewardship agreement to reduce emissions from deforestation and degradation (REDD): Lubuk Beringin's Hutan Desa as the first village forest in Indonesia

103. Landscape dynamics over time and space from ecological perspective

104. Komoditisasi atau koinvestasi jasa lingkungan: skema imbal jasa lingkungan program peduli sungai di DAS Way Besai, Lampung, Indonesia

105. Improving smallholders' rubber quality in Lubuk Beringin, Bungo district, Jambi province, Indonesia: an initial analysis of the financial and social benefits

106. Rapid Carbon Stock Appraisal (RACSA) in Kalahan, Nueva Vizcaya, Philippines

107. Tree domestication by ICRAF and partners in the Peruvian Amazon: lessons learned and future prospects in the domain of the Amazon Initiative eco-regional program

108. Memorias del Taller Nacional: "Iniciativas para Reducir la Deforestación en la region Andino Amazónica", 09 de Abril del 2010. Proyecto REALU Peru

109. Percepciones sobre la Equidad y Eficiencia en la cadena de valor de REDD en Perú - Reporte de Talleres en Ucayali, San Martín y Loreto, 2009. Proyecto REALU-Perú.

110. Reducción de emisiones de todos los Usos del Suelo. Reporte del Proyecto REALU Perú Fase 1

111. Programa Alternativas a la Tumba-y-Quema (ASB) en el Perú. Informe Resumen y Síntesis de la Fase II. 2da. versión revisada

112. Estudio de las cadenas de abastecimiento de germoplasma forestal en la amazonía Boliviana 
113. Biodiesel in the Amazon

114. Estudio de mercado de semillas forestales en la amazonía Colombiana

115. Estudio de las cadenas de abastecimiento de germoplasma forestal en Ecuador http://dx.doi.org10.5716/WP10340.PDF

116. How can systems thinking, social capital and social network analysis help programs achieve impact at scale?

117. Energy policies, forests and local communities in the Ucayali Region, Peruvian Amazon

118. NTFPs as a Source of Livelihood Diversification for Local Communities in the Batang Toru Orangutan Conservation Program

119. Studi Biodiversitas: Apakah agroforestry mampu mengkonservasi keanekaragaman hayati di DAS Konto?

120. Estimasi Karbon Tersimpan di Lahan-lahan Pertanian di DAS Konto, Jawa Timur

121. Implementasi Kaji Cepat Hidrologi (RHA) di Hulu DAS Brantas, Jawa Timur. http://dx.doi.org/10.5716/WP10338.PDF

122. Kaji Cepat Hidrologi di Daerah Aliran Sungai Krueng Peusangan, NAD,Sumatra http://dx.doi.org/10.5716/WP10337.PDF

123. A Study of Rapid Hydrological Appraisal in the Krueng Peusangan Watershed, NAD, Sumatra. http://dx.doi.org/10.5716/WP10339.PDF

\section{1}

124. An Assessment of farm timber value chains in Mt Kenya area, Kenya

125. A Comparative financial analysis of current land use systems and implications for the adoption of improved agroforestry in the East Usambaras, Tanzania

126. Agricultural monitoring and evaluation systems

127. Challenges and opportunities for collaborative landscape governance in the East Usambara Mountains, Tanzania

128. Transforming Knowledge to Enhance Integrated Natural Resource Management Research, Development and Advocacy in the Highlands of Eastern Africa. http://dx.doi.org/10.5716/WP11084.PDF

129. Carbon-forestry projects in the Philippines: potential and challenges The Mt Kitanglad Range forest-carbon development. http://dx.doi.org10.5716/WP11054.PDF

130. Carbon forestry projects in the Philippines: potential and challenges. The Arakan Forest Corridor forest-carbon project. http://dx.doi.org10.5716/WP11055.PDF

131. Carbon-forestry projects in the Philippines: potential and challenges. The Laguna Lake Development Authority's forest-carbon development project. http://dx.doi.org/10.5716/WP11056.PDF

132. Carbon-forestry projects in the Philippines: potential and challenges. The Quirino forest-carbon development project in Sierra Madre Biodiversity Corridor. http://dx.doi.org10.5716/WP11057.PDF

133. Carbon-forestry projects in the Philippines: potential and challenges. The Ikalahan Ancestral Domain forest-carbon development. http://dx.doi.org10.5716/WP11058.PDF

134. The Importance of Local Traditional Institutions in the Management of Natural Resources in the Highlands of Eastern Africa. http://dx.doi.org/10.5716/WP11085.PDF

135. Socio-economic assessment of irrigation pilot projects in Rwanda. http://dx.doi.org/10.5716/WP11086.PDF

136. Performance of three rambutan varieties(Nephelium lappaceum L.) on various nursery media. http://dx.doi.org/10.5716/WP11232.PDF 
137. Climate change adaptation and social protection in agroforestry systems: enhancing adaptive capacity and minimizing risk of drought in Zambia and Honduras.

http://dx.doi.org/10.5716/WP11269.PDF

138. Does value chain development contribute to rural poverty reduction? Evidence of asset building by smallholder coffee producers in Nicaragua. http://dx.doi.org/10.5716/WP11271.PDF

139. Potential for biofuel feedstock in Kenya. http://dx.doi.org/10.5716/WP11272.PDF

140. Impact of fertilizer trees on maize production and food security in six districts of Malawi. http://dx.doi.org/10.5716/WP11281.PDF

\section{2}

141. Fortalecimiento de capacidades para la gestión del Santuario Nacional Pampa Hermosa:

Construyendo las bases para un manejo adaptativo para el desarrollo local. Memorias del Proyecto. http://dx.doi.org/10.5716/WP12005.PDF

142. Understanding rural institutional strengthening: A cross-level policy and institutional framework for sustainable development in Kenya. http://dx.doi.org/10.5716/WP12012.PDF

143. Climate change vulnerability of agroforestry. http://dx.doi.org/10.5716/WP16722.PDF

144. Rapid assesment of the inner Niger delta of Mali. http://dx.doi.org/10.5716/WP12021.PDF

145. Designing an incentive program to reduce on-farm deforestationin the East Usambara Mountains, Tanzania. http://dx.doi.org/10.5716/WP12048.PDF

146. Extent of adoption of conservation agriculture and agroforestry in Africa: the case of Tanzania, Kenya, Ghana, and Zambia. http://dx.doi.org/10.5716/WP12049.PDF

147. Policy incentives for scaling up conservation agriculture with trees in Africa: the case of Tanzania, Kenya, Ghana and Zambia. http://dx.doi.org/10.5716/WP12050.PDF

148. Commoditized or co-invested environmental services? Rewards for environmental services scheme: River Care program Way Besai watershed, Lampung, Indonesia. http://dx.doi.org/10.5716/WP12051.PDF

149. Assessment of the headwaters of the Blue Nile in Ethiopia. http://dx.doi.org/10.5716/WP12160.PDF

150. Assessment of the uThukela Watershed, Kwazaulu. http://dx.doi.org/10.5716/WP12161.PDF

151. Assessment of the Oum Zessar Watershed of Tunisia. http://dx.doi.org/10.5716/WP12162.PDF

152. Assessment of the Ruwenzori Mountains in Uganda. http://dx.doi.org/10.5716/WP12163.PDF

153. History of agroforestry research and development in Viet Nam. Analysis of research opportunities and gaps. http://dx.doi.org/10.5716/WP12052.PDF

154. REDD+ in Indonesia: a Historical Perspective. http://dx.doi.org/10.5716/WP12053.PDF

155. Agroforestry and Forestry in Sulawesi series: Livelihood strategies and land use system dynamics in South Sulawesi http://dx.doi.org/10.5716/WP12054.PDF

156. Agroforestry and Forestry in Sulawesi series: Livelihood strategies and land use system dynamics in Southeast Sulawesi. http://dx.doi.org/10.5716/WP12055.PDF

157. Agroforestry and Forestry in Sulawesi series: Profitability and land-use systems in South and Southeast Sulawesi. http://dx.doi.org/10.5716/WP12056.PDF

158. Agroforestry and Forestry in Sulawesi series: Gender, livelihoods and land in South and Southeast Sulawesi http://dx.doi.org/10.5716/WP12057.PDF

159. Agroforestry and Forestry in Sulawesi series: Agroforestry extension needs at the community level in AgFor project sites in South and Southeast Sulawesi, Indonesia. http://dx.doi.org/10.5716/WP12058.PDF

160. Agroforestry and Forestry in Sulawesi series: Rapid market appraisal of agricultural, plantation and forestry commodities in South and Southeast Sulawesi. http://dx.doi.org/10.5716/WP12059.PDF 


\section{3}

161. Diagnosis of farming systems in the Agroforestry for Livelihoods of Smallholder farmers in Northwestern Viet Nam project. http://dx.doi.org/10.5716/WP13033.PDF

162. Ecosystem vulnerability to climate change: a literature review. http://dx.doi.org/10.5716/WP13034.PDF

163. Local capacity for implementing payments for environmental services schemes: lessons from the RUPES project in northeastern Viet Nam. http://dx.doi.org/10.5716/WP13046.PDF

164. Seri Agroforestri dan Kehutanan di Sulawesi: Agroforestry dan Kehutanan di Sulawesi: Strategi mata pencaharian dan dinamika sistem penggunaan lahan di Sulawesi Selatan. http://dx.doi.org/10.5716/WP13040.PDF

165. Seri Agroforestri dan Kehutanan di Sulawesi: Mata pencaharian dan dinamika sistem penggunaan lahan di Sulawesi Tenggara http://dx.doi.org/10.5716/WP13041.PDF

166. Seri Agroforestri dan Kehutanan di Sulawesi: Profitabilitas sistem penggunaan lahan di Sulawesi Selatan dan Sulawesi Tenggara http://dx.doi.org/10.5716/WP13042.PDF

167. Seri Agroforestri dan Kehutanan di Sulawesi: Gender, mata pencarian dan lahan di Sulawesi Selatan dan Sulawesi Tenggara http://dx.doi.org/10.5716/WP13043.PDF

168. Seri Agroforestri dan Kehutanan di Sulawesi: Kebutuhan penyuluhan agroforestri pada tingkat masyarakat di lokasi proyek AgFor di Sulawesi Selatan dan Tenggara, Indonesia. http://dx.doi.org/10.5716/WP13044.PDF

169. Seri Agroforestri dan Kehutanan di Sulawesi: Laporan hasil penilaian cepat untuk komoditas pertanian, perkebunan dan kehutanan di Sulawesi Selatan dan Tenggara. http://dx.doi.org/10.5716/WP13045.PDF

170. Agroforestry, food and nutritional security. http://dx.doi.org/10.5716/WP13054.PDF

171. Stakeholder Preferences over Rewards for Ecosystem Services: Implications for a REDD+ Benefit Distribution System in Viet Nam. http://dx.doi.org/10.5716/WP13057.PDF

172. Payments for ecosystem services schemes: project-level insights on benefits for ecosystems and the rural poor. http://dx.doi.org/10.5716/WP13001.PDF 

The World Agroforestry Centre is an autonomous, non-profit research organization whose vision is a rural transformation in the developing world as smallholder households increase their use of trees in agricultural landscapes to improve food security, nutrition, income, health, shelter, social cohesion, energy resources and environmental sustainability. The Centre generates science-based knowledge about the diverse roles that trees play in agricultural landscapes, and uses its research to advance policies and practices, and their implementation that benefit the poor and the environment. It aims to ensure that all this is achieved by enhancing the quality of its science work, increasing operational efficiency, building and maintaining strong partnerships, accelerating the use and impact of its research, and promoting greater cohesion, interdependence and alignment within the organization.

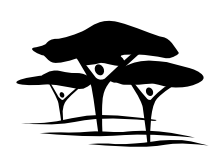

United Nations Avenue, Gigiri • PO Box 30677 • Nairobi, $00100 \cdot$ Kenya Telephone: +254207224000 or via USA +1 6508336645

Fax: +254207224001 or via USA +1 6508336646

Email: worldagroforestry@cgiar.org •www.worldagroforestry.org

Southeast Asia Regional Program • Sindang Barang • Bogor 16680

PO Box $161 \cdot$ Bogor $16001 \cdot$ Indonesia

Telephone: +62 $2518625415 \cdot$ Fax: +62 2518625416

Email: icraf-indonesia@cgiar.org•www.worldagroforestry.org/regions/southeast_asia 